\title{
COVID-19 REPORT $11^{\mathrm{TH}}$ EDITION
}

GLOBAL OUTBREAK OVERVIEW AND ITS IMPACT ON THE ENERGY SECTOR

20 MAY 2020

PUBLIC VERSION 
Table of Contents

Executive summary

Outbreak status and outlook

Impact on oil demand

Impact on the oil and gas industry

Methodology 


\section{Road traffic up while the markets briefly rally on fragile vaccine hopes}

Have we seen more good news or bad news in the past week? On the positive side, we observe that daily fatality rates continue to fall in East Asia, Europe and North America, and countries in these regions are beginning to reopen after two months of lockdown. In China, residents are free to travel domestically starting this week. However, there is an understanding that the government is monitoring every move and will implement quarantine measures quickly if a new wave of infection is detected. Moreover, we have seen positive news from the medical company Moderna stating that the first round of testing for its Covid-19 vaccination was successful, creating a rally in the stock market. We have also seen reports indicating that herd immunity may be achieved in populations with just $20 \%$ to $40 \%$ of people infected due to population heterogeneity. For example, "super-spreaders" which are very social individuals, will be immune first.

However, on the negative side, we see that despite lockdown-measures in South America, South Asia and the Middle East, it does not appear that daily fatalities have peaked, meaning that the exponential spread of the virus continues. The epicenter of the pandemic has moved from East Asia to Europe, and then to North America; it now appears that South America and South Asia could be the next epicenters. Still, it is clear from antibody testing in Spain and other places that herd immunity will not be within reach for many months, as preliminary results indicate that even in hard-hit countries like Spain, only $5 \%$ of the population has been infected. The vaccination optimism has also cooled down, as experts have not been convinced by Moderna's data that their antibody-based vaccine will be effective. Many scientists claim that the autumn of 2021 is the most realistic timeline when we may see global vaccination programs. Increasing international rivalry, rather than cooperation, does not appear to be a good sign.

Thus, we reflect on a quite balanced week overall, as global citizens begin to accept that it will take at least 12 to 18 months before the world fully normalizes.

For the oil market, we see good news in that road traffic is clearly coming back; In May we expect to see the largest month-overmonth growth in history. Additional international storage has also been mobilized in the past week, and OPEC + cuts are actually happening, pushing the potential storage abyss out in time.
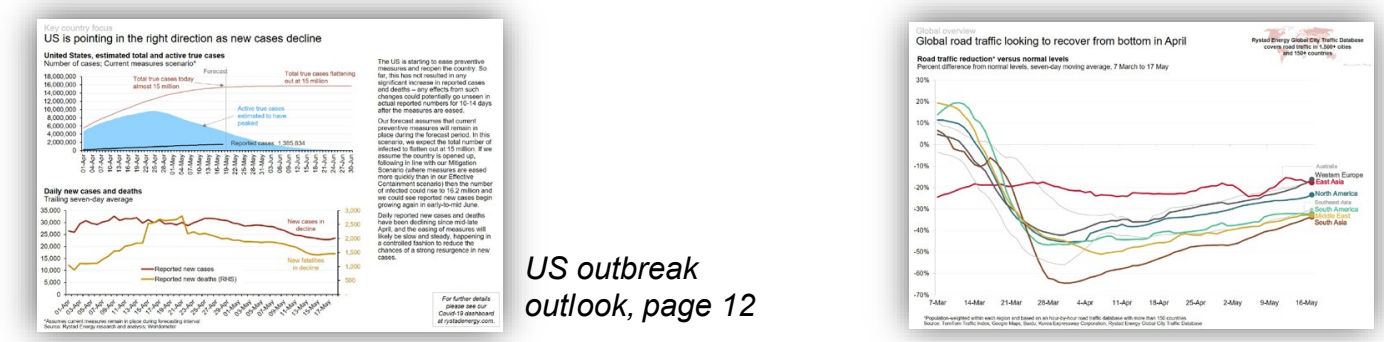

Road traffic update, page 17

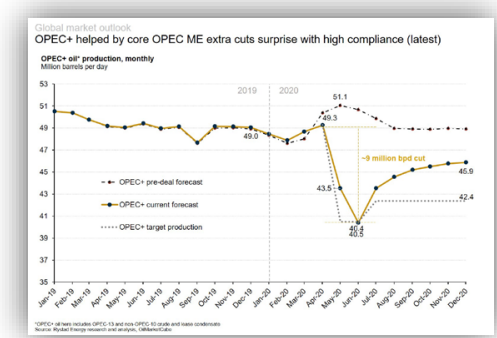

OPEC+ production cuts, page 31 
Table of Contents

\section{Executive summary}

Outbreak status and outlook

- Global overview

- Key country focus

Impact on oil demand

Impact on the oil and gas industry

Methodology 


\section{The true cumulative number of people infected globally today is likely 64 million}

\section{Number of true and reported cases}

\section{Cases (log scale), Current measures scenario*}

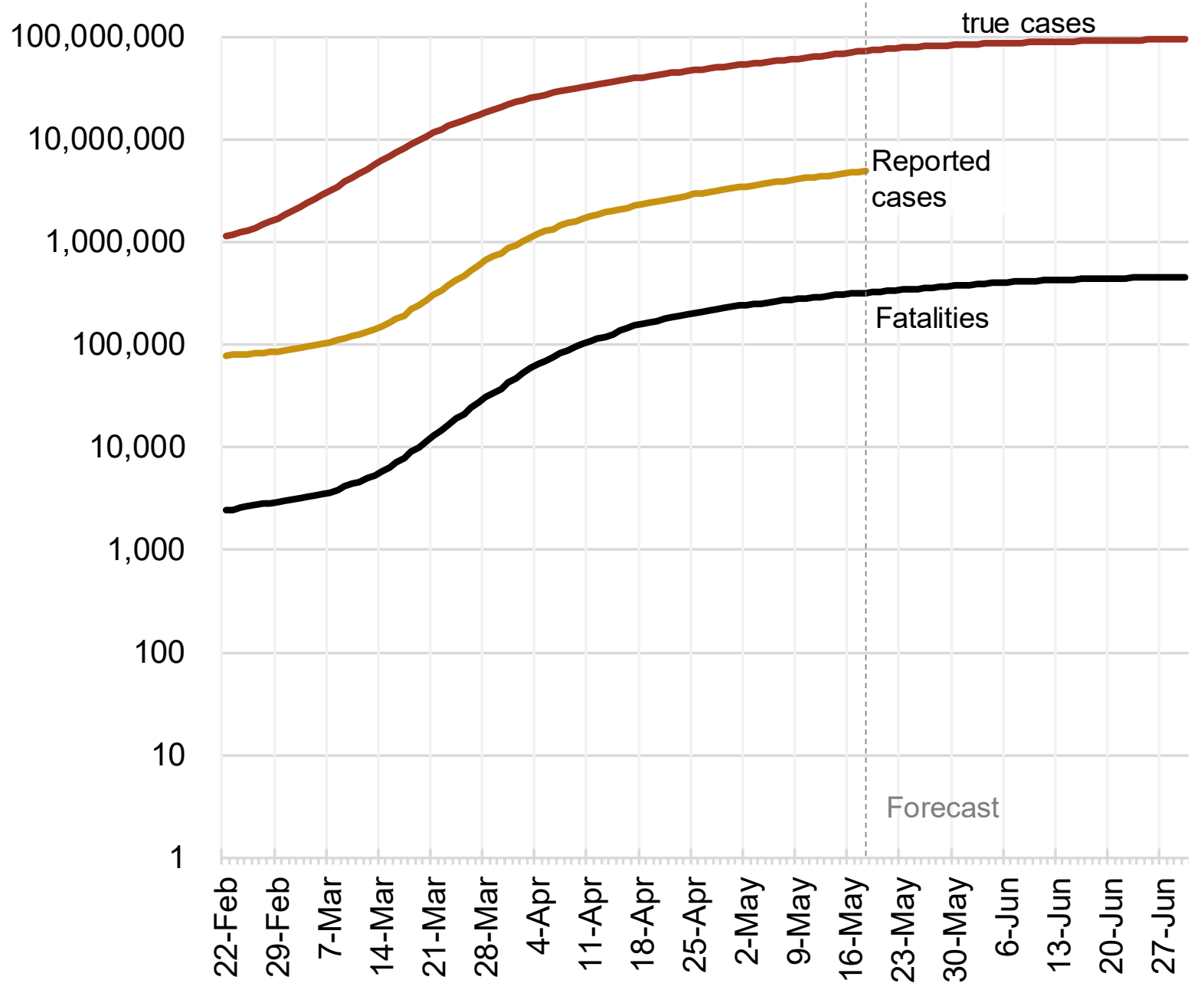

As of 18 May, 72 million people have likely been infected with Covid-19, according to our updated model.

Reported cases were almost 4.9 million as of 18 May, a number which our analysis suggests represents just $7 \%$ of true cases. Reported cases are now growing at only approximately $2 \%$ per day (7-day trailing average), a growth rate which has somewhat stabilized. This is an indication that quarantine measures are working. Growth is no longer exponential, but now appears linear, with 80,000-85,000 new reported cases per day on average over the last three weeks

Registered fatalities globally were almost 320,000 as of 18 May, a number which has also stabilized at a $2 \%$ growth rate (trailing 7 -day average).

Our forecast assumes current strict measures will remain in place until the end of June. In this scenario, 95 million people will be infected across the globe by the end of June. 


\section{No countries in the Americas have implemented lockdowns as strict as in France}

Retail and recreation activity (restaurants, shopping centers, etc)

Percent above or below normal levels based on Google mobility data (7-day average)

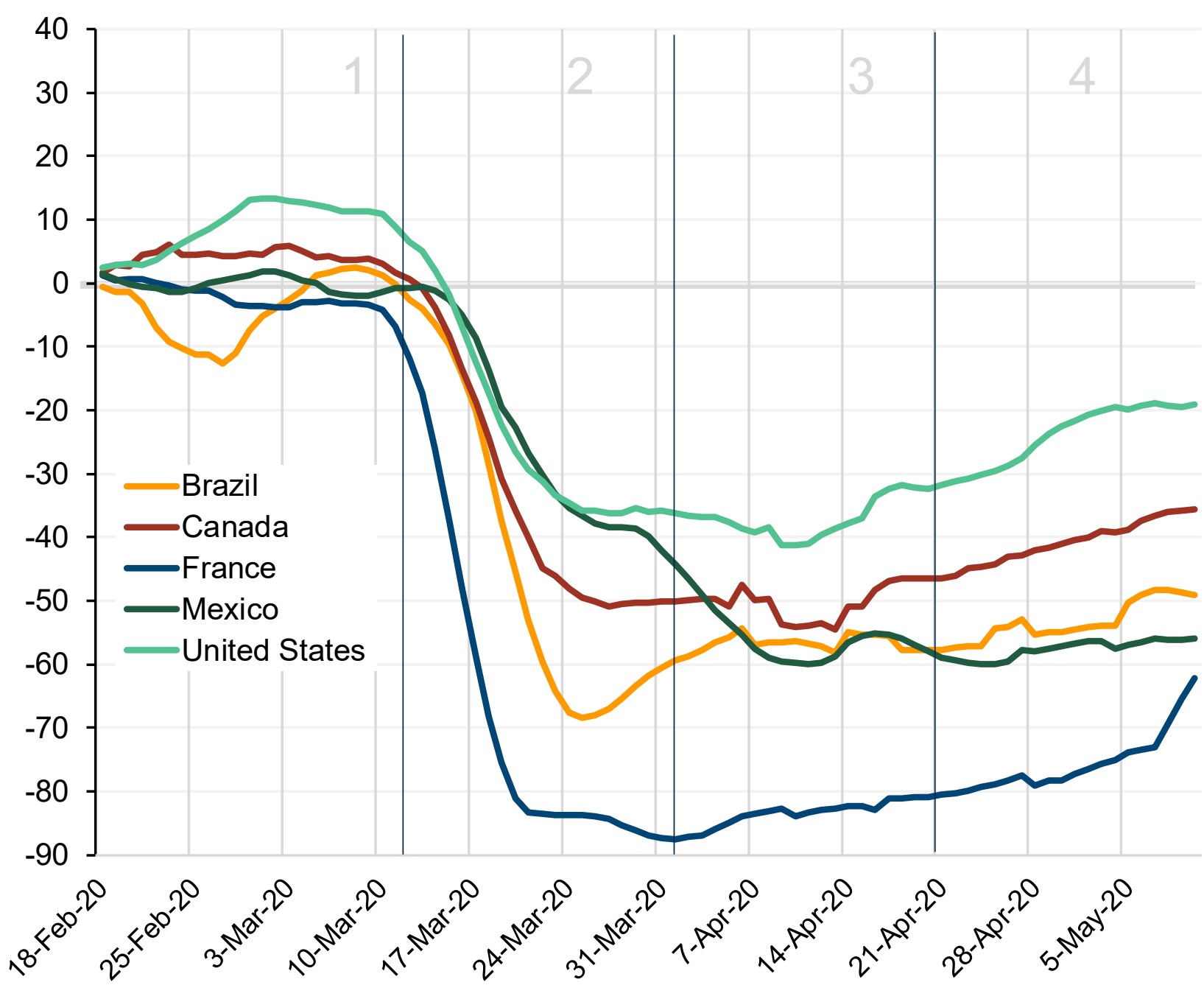

Source: Rystad Energy Covid-19 model; Google Mobility data
To the left we see recreation activity in four countries in the Americas, plus France for comparison. No countries in the Americas have applied the same strict country-wide lockdowns as in France. It should be noted that the extreme virus spread in New York City has other drivers, such as population density and the presence of contamination over the entire month of February.

Fatality rate as of 20 May per 100,000:

- Canada: 16

- Mexico: 4

- USA: 28 (New York: 147)

- Brazil: 9

- France: 43

\begin{tabular}{|c|c|c|c|c|}
\hline & \multicolumn{3}{|c|}{ Start of 21-day period } & \\
\hline & $\begin{array}{c}22 \\
\text { Feb }\end{array}$ & $\begin{array}{c}13 \\
\text { March }\end{array}$ & 3 April & 21 April \\
\hline Country & $\mathrm{R}_{\text {eff }}$ & $\mathrm{R}_{\text {eff }}$ & $\mathrm{R}_{\text {eff }}$ & $\mathrm{R}_{\text {eff }}$ \\
\hline Canada & 2.6 & 2.0 & 1.1 & 0.8 \\
\hline Mexico & 2.8 & 2.1 & 1.5 & 1.3 \\
\hline USA & 3.9 & 1.6 & 0.9 & 0.8 \\
\hline Brazil & 3.6 & 1.8 & 1.4 & 1.1 \\
\hline France & 3.1 & 1.2 & 0.7 & 0.8 \\
\hline
\end{tabular}




\section{Differences in work place activity explains cases in the Middle East}

\section{Work place activity (stay at work, rather than work from home)}

Percent above or below normal levels based on Google mobility data (7-day average)

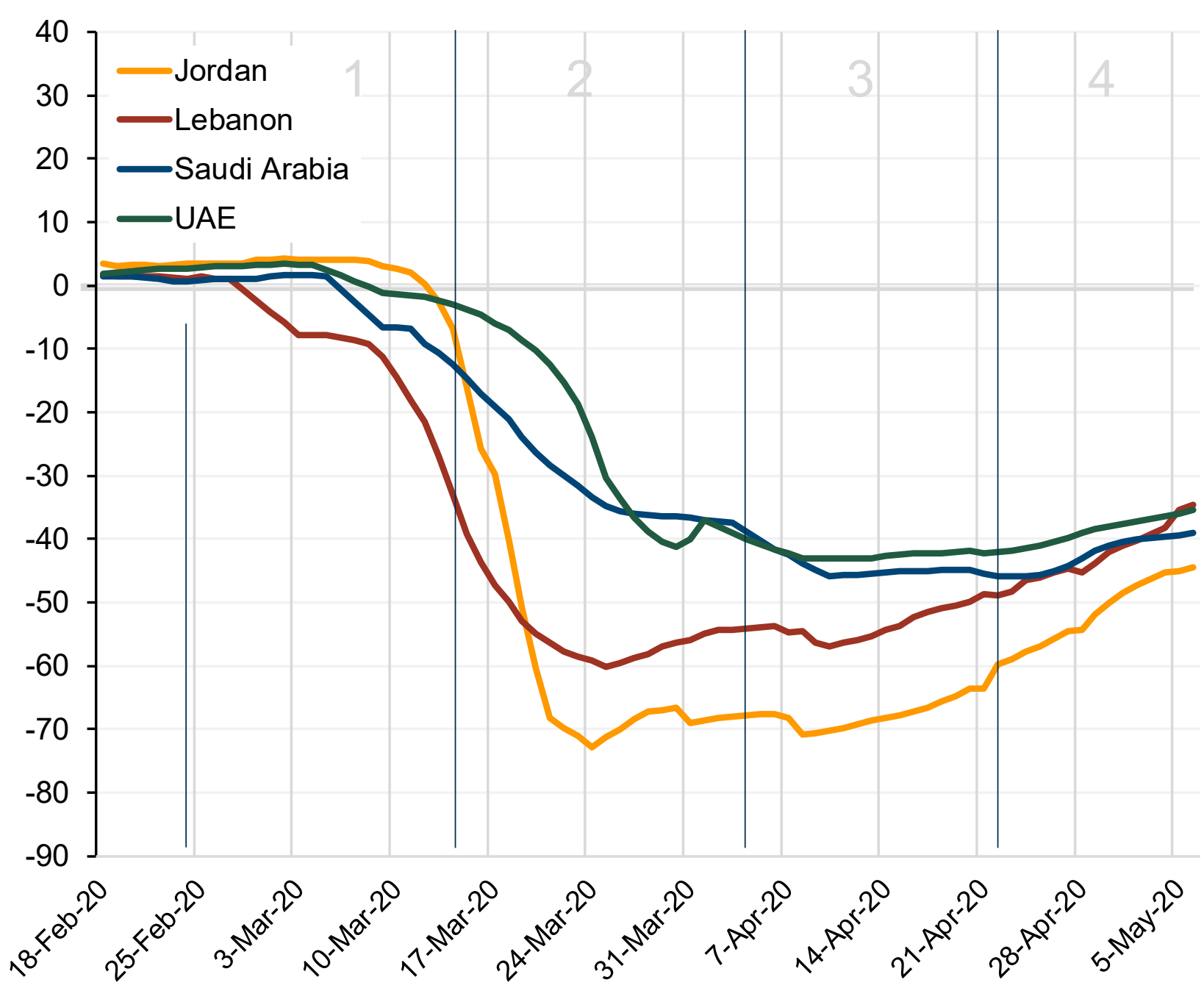

To the left we see work place activity for four countries in the Middle East. As seen, UAE and Saudi Arabia work place presence was reduced more slowly and was more shallow than in Jordan and Lebanon. The latter two acheived an $R_{\text {eff }}$ below 1.0 from mid March, while UAE and Saudi Arabia still have not achieved an $R_{\text {eff }}$ lower than 1.0, meaning that new cases are still growing.

Ratality rates as of 19 May per 100,000:

- UAE: 2.3

- Saudi Arabia: 0.9

- Lebanon: 0.4

- Jordan: 0.1

\begin{tabular}{|c|c|c|c|c|}
\hline & \multicolumn{3}{|c|}{ Start of 21-day period } & \multirow[b]{2}{*}{21 April } \\
\hline & $22 \mathrm{Feb}$ & $\begin{array}{c}13 \\
\text { March }\end{array}$ & 3 April & \\
\hline Country & $R_{\text {eff }}$ & $R_{\text {eff }}$ & $R_{\text {eff }}$ & $R_{\text {eff }}$ \\
\hline UAE & 2.2 & 1.7 & 1.4 & 1.1 \\
\hline $\begin{array}{l}\text { Saudi } \\
\text { Arabia }\end{array}$ & 3.8 & 1.5 & 1.2 & 1.3 \\
\hline Lebanon & 2.2 & 0.8 & 0.8 & 1.0 \\
\hline Jordan & 2.5 & 1.0 & 0.9 & 0.9 \\
\hline
\end{tabular}




\section{Low fatality rates so far in South Asia, but three out of four countries are still growing}

\section{Transit station activity (subway, bus or train stations)}

Percent above or below normal levels based on Google mobility data (7-day average)

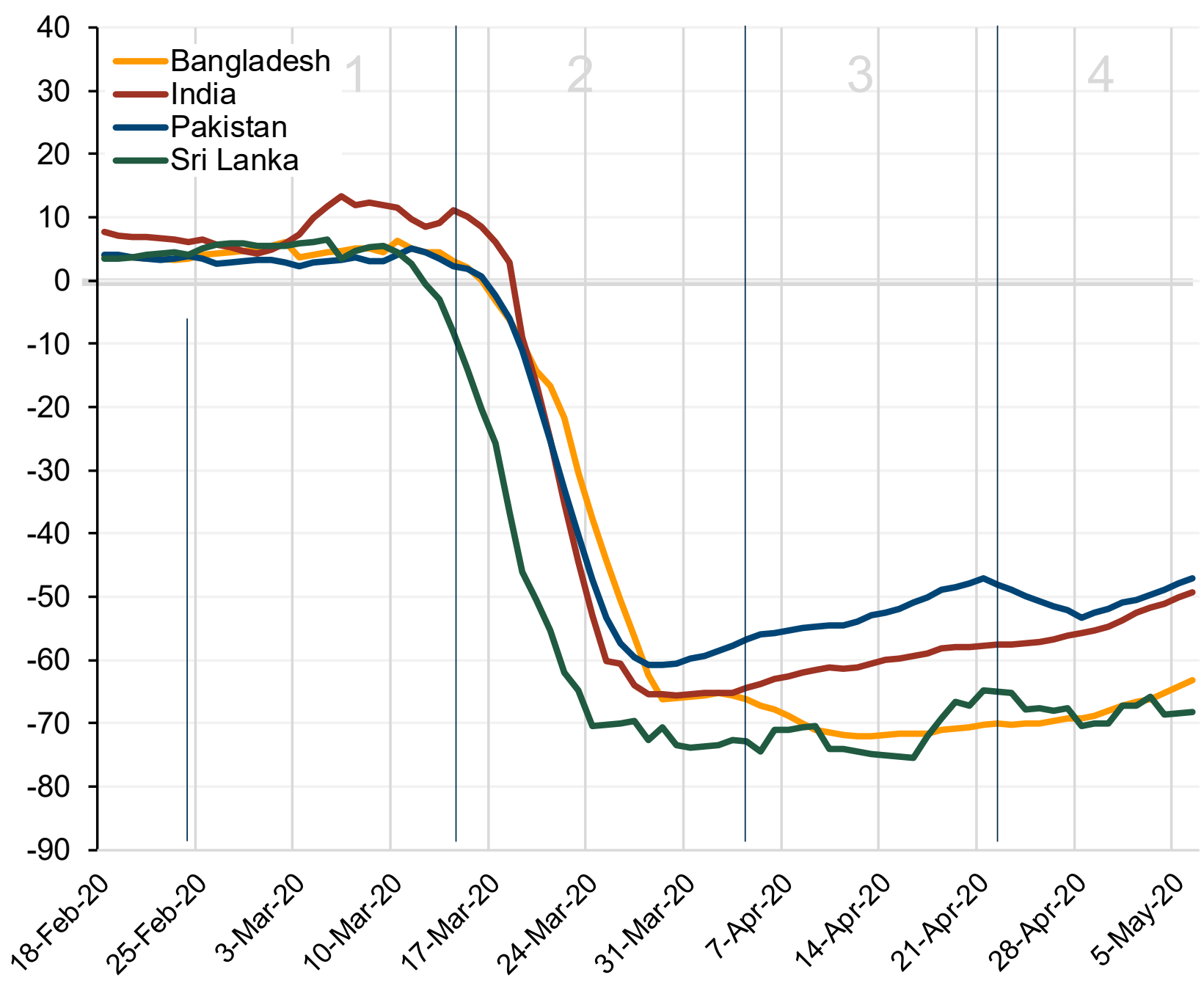

In South Asia, Sri Lanka was the first country to introduce strict measures and have also maintained measures the longest. This has paid off, as the number of fatalities per 100,000 in population is only 10 . versus Pakistan, which has practiced slightly looser measures.

Fatality rate as of 19 May per 100,000:

- Bangladesh: 0.2

- India: 0.2

- Pakistan: 0.4

- Sri Lanka: 0.04

\begin{tabular}{|c|c|c|c|c|}
\hline & \multicolumn{3}{|c|}{ Start of 21-day period } & \multirow[b]{2}{*}{21 April } \\
\hline & $\begin{array}{c}22 \\
\text { Feb }\end{array}$ & $\begin{array}{c}13 \\
\text { March }\end{array}$ & 3 April & \\
\hline Country & $\mathrm{R}_{\mathrm{eff}}$ & $R_{\text {eff }}$ & $\mathrm{R}_{\mathrm{eff}}$ & $R_{\text {eff }}$ \\
\hline Bangladesh & 1.8 & 2.2 & 0.9 & 1.8 \\
\hline India & 2.7 & 1.7 & 1.4 & 1.1 \\
\hline Pakistan & 2.6 & 1.5 & 1.3 & 1.3 \\
\hline Sri Lanka & 3.0 & 1.0 & 0.9 & 0.9 \\
\hline
\end{tabular}




\section{Claims that a vaccine could be ready by the end of 2020 are probably too optimistic}

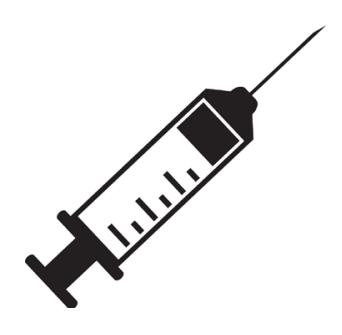

- Dozens of companies and universities are attempting to make Covid-19 vaccines, including Pfizer/BioNTech, CanSino, and the University of Oxford/AstraZeneca

- As of this week, the most optimistic estimates do not expect a vaccine for the next 12-18 months, thus well into 2021.

- Vaccines are seen as the best solution to fully recover from the pandemic as achieving herd immunity comes with many uncertainties, such as timing and risk of resurgence

- This explains why stock markets and oil prices rose following news from biotechnology company Moderna

- On Monday 18 May, Moderna announced it had successfully completed an initial Phase 1 testing round. Eight healthy volunteers ages 18-55 found the experimental vaccine safe and saw that it provoked an immune response.

- The vaccine is on an accelerated time table to begin Phase 2 testing on 600 people in $2 \mathrm{Q}$. The testing group will be split into two cohorts of 300 , one aged 18-55, and another aged 55 and above.

- A third testing phase with 30,000 people will begin in July.

- If trials go well, the vaccine could reportedly become available by late 2020/early 2021

- Moderna claims it has a production capacity of 1 billion of the smallest doses $(50 \mu \mathrm{m})$ per year.

- However, experts remain skeptical, and Moderna has produced little documentation to support its claims.

- After rallying, Moderna stock fell again this week after initial news, hinting at continued uncertainty. 


\section{The worst may be behind in Canada, as cases and fatalities decline}

Canada, estimated total and active true cases

Number of cases; Current measures scenario*

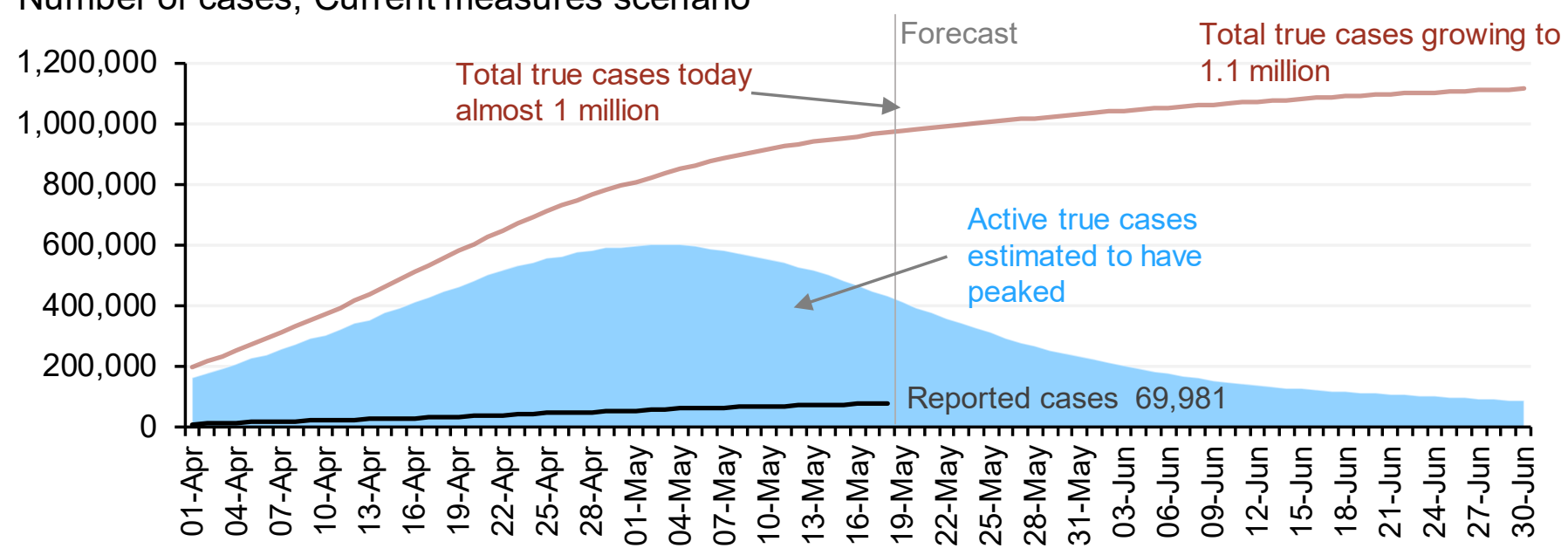

Daily new cases and deaths

Trailing seven-day average

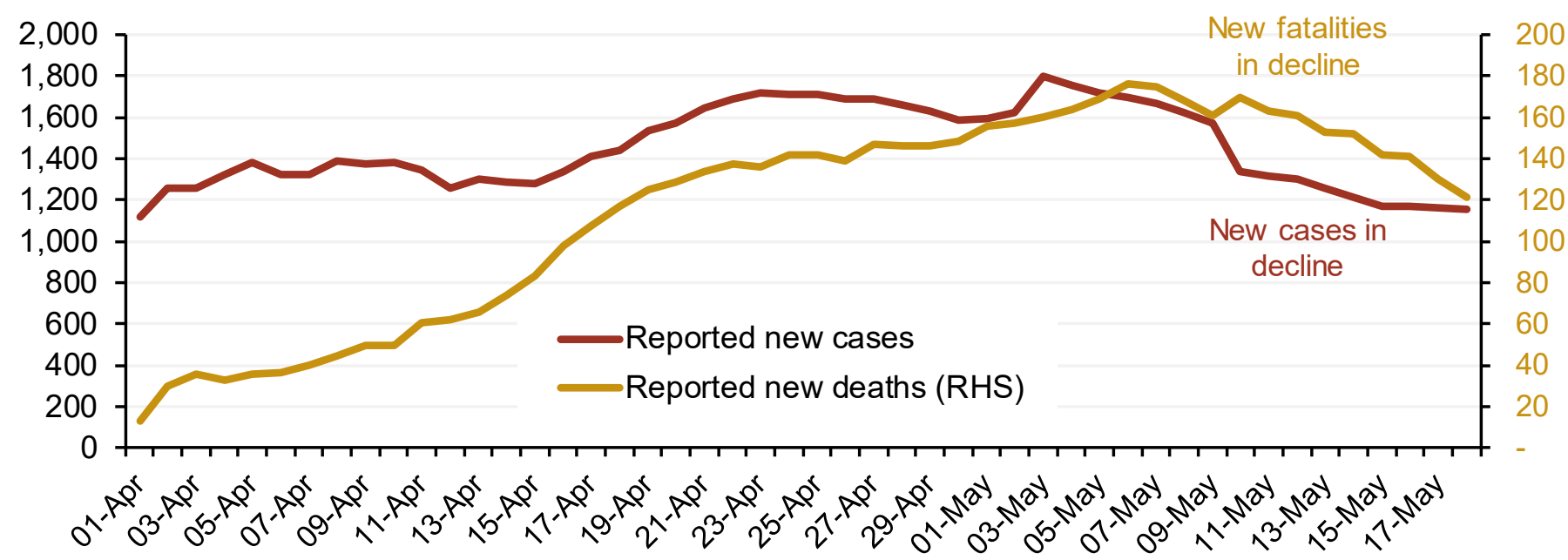

*Assumes current measures remain in place during forecasting interval 


\section{Key country focus}

\section{Saudi Arabia still is showing growth in spread, but may be about to peak}

\section{Saudi Arabia, estimated total and active true cases}

Number of cases; Current measures scenario*

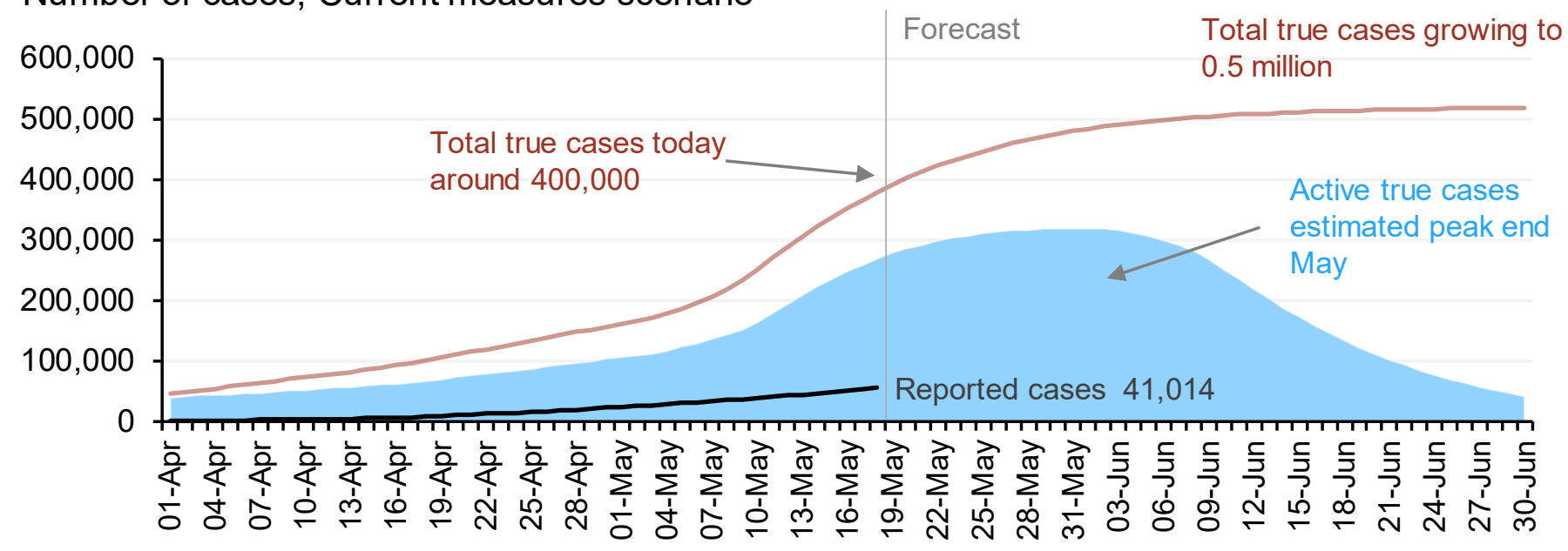

Daily new cases and deaths

Trailing seven-day average

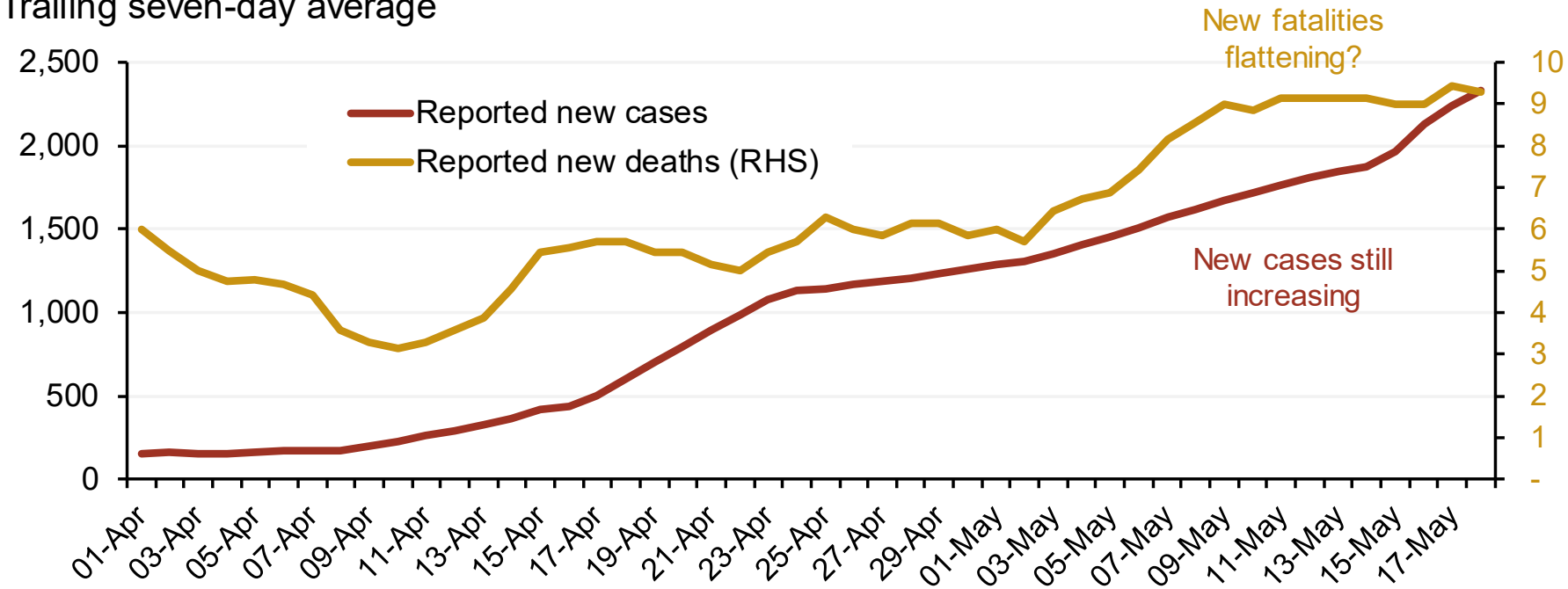


Table of Contents

\section{Executive summary}

Outbreak status and outlook

Impact on oil demand

- Global overview

- Aviation and jet fuels

- Ground transportation and road fuels

Impact on the oil and gas industry

Methodology 


\section{Global overview}

Global road traffic looking to recover from bottom in April

Rystad Energy Global City Traffic Database covers road traffic in $1,500+$ cities and $150+$ countries

\section{Road traffic reduction* versus normal levels}

Percent difference from normal levels, seven-day moving average, 7 March to 17 May

$30 \%$

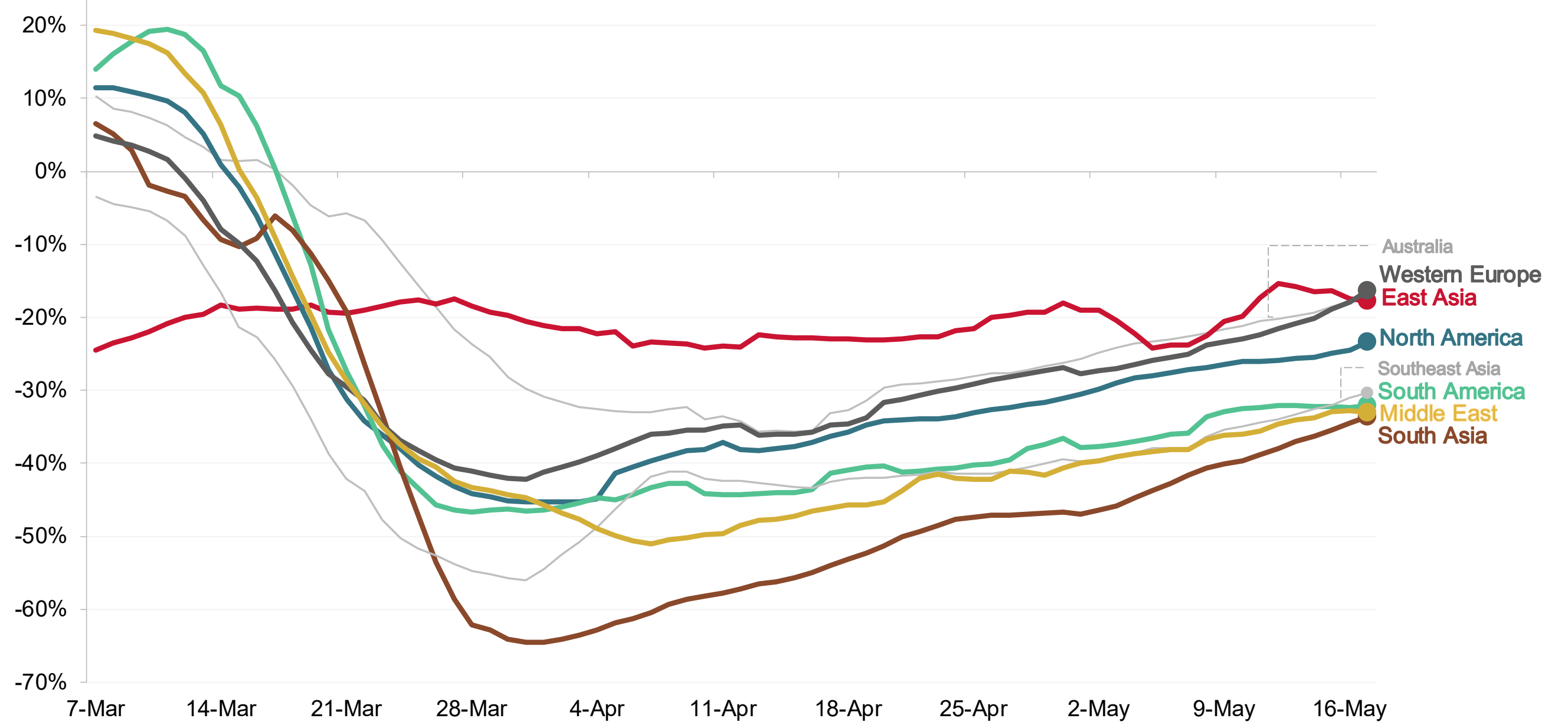

${ }^{*}$ Population-weighted within each region and based on an hour-by-hour road traffic database with more than 150 countries

Source: TomTom Traffic Index; Google Maps; Baidu; Korea Expressway Corporation; Rystad Energy Global City Traffic Database 


\section{From a low of 72 million bpd, oil demand recovers by 6 million bpd every month, May-July}

Global oil demand impact analysis of Covid-19 by region, levels and changes vs. pre-virus estimates

Thousand barrels per day

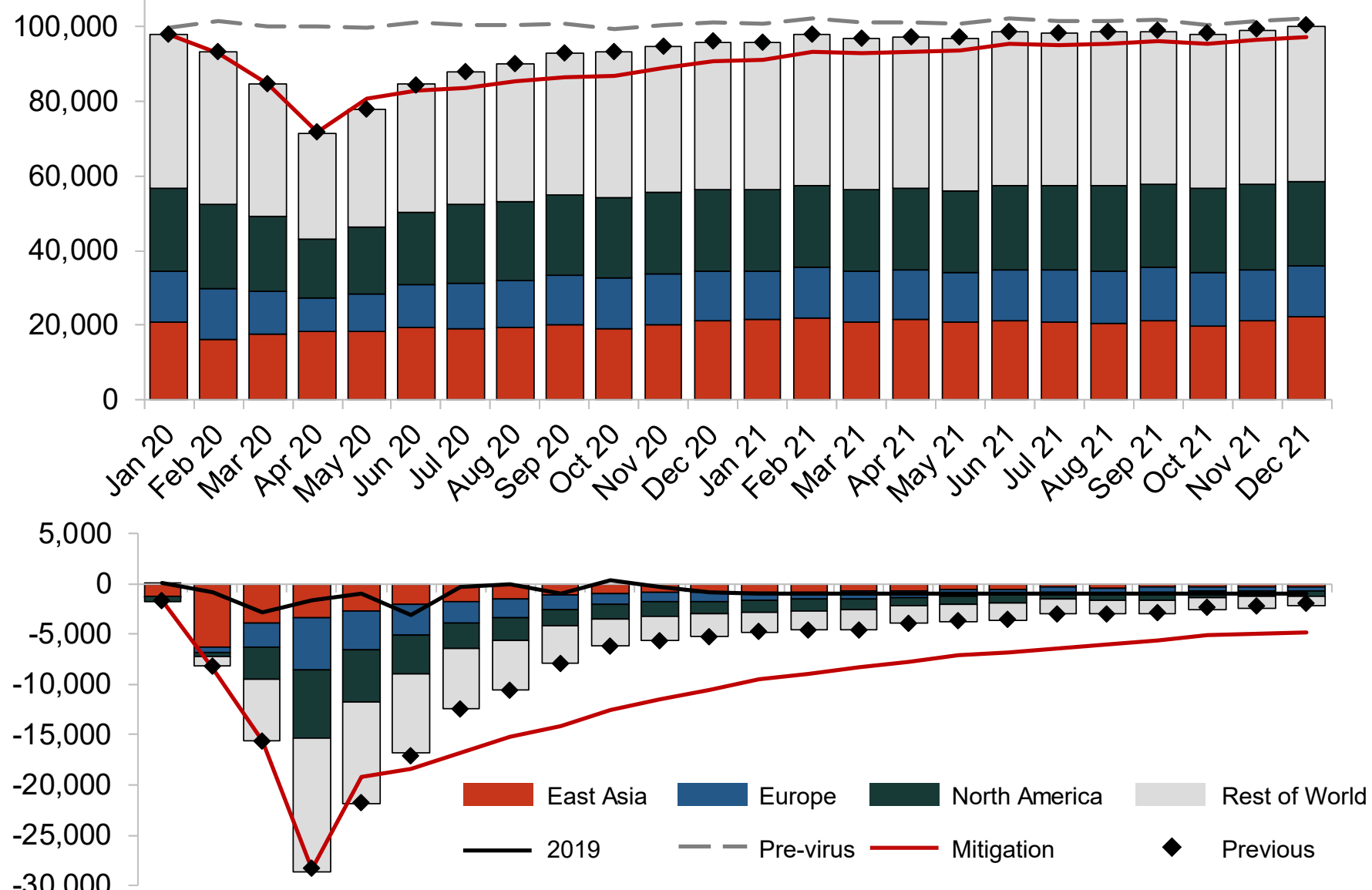

$-30,000$

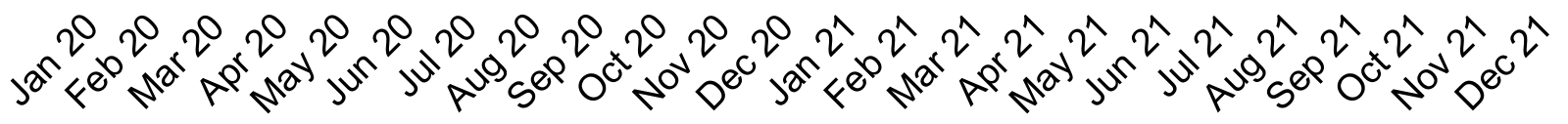

\section{Remaining barrels}

Oil demand has taken an $\mathbf{r}$-shaped dip, reaching a low point in April and improving in May and June.

The December 2020 level is expected at 96 million bpd, with a potential downside to 90 million bpd. Significant downside risks will linger far into 2021.

Average demand for 2020 is expected at 89 million bpd, a drop of $11 \%$ from 2019. Average demand for 2021 is seen at 98 million bpd.

Europe is the worst hit, with demand in April down 38\% year-on-year and a $13 \%$ demand decline expected for 2020 as a whole.

\section{Lost barrels}

About 4 billon barrels will be removed from global oil demand during 2020.

More than half of this decline comes from areas outside the main demand pools of East Asia, Europe and North America.

In our downside scenario, we see global demand impact remaining down by 10.5 million bpd in December 2020 and 4.8 million bpd in December 2021. 


\section{Recovery seen in aviation activity in East Asia, Europe still at 90\% reduction y/y}

Scheduled flight cancellations after 500 reported cases in weeks

Year-on-year change

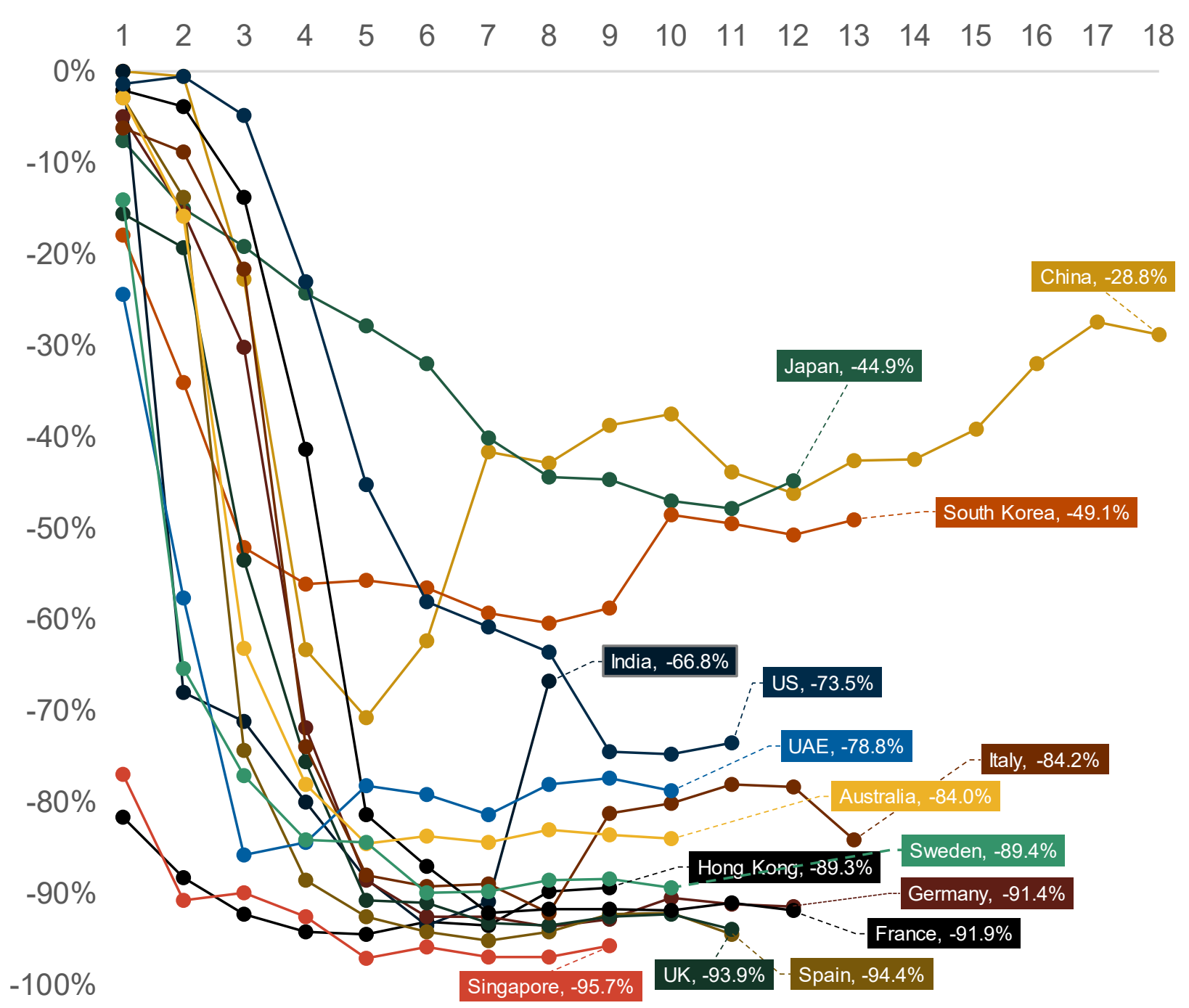

Aviation is set to stabilize in many countries as the summer peak of June and July

approaches and major airlines have extended their flight cancellation schedule.

The US had a significant increase in the number of cancellations in week 9 , and is set to reach a new floor of negative $73.5 \%$ cancellations.

Year-on-year scheduled flight cancellations in China have increased the past five weeks and seem to stabilize at a new plateau at negative $28.8 \%$ cancellations.

Much of Europe is still in lockdown when it comes to air travel, reflected in flight cancellations of around $90 \%$ in the busiest travel hubs in Europe. 
Road fuel is down $11 \%$ for the year, jet fuel down $33 \%$ and all other fuels down $7 \%$ vs 2019

Global oil demand impact analysis of Covid-19 by fuel, levels and changes vs pre-virus estimates

Thousand barrels per day

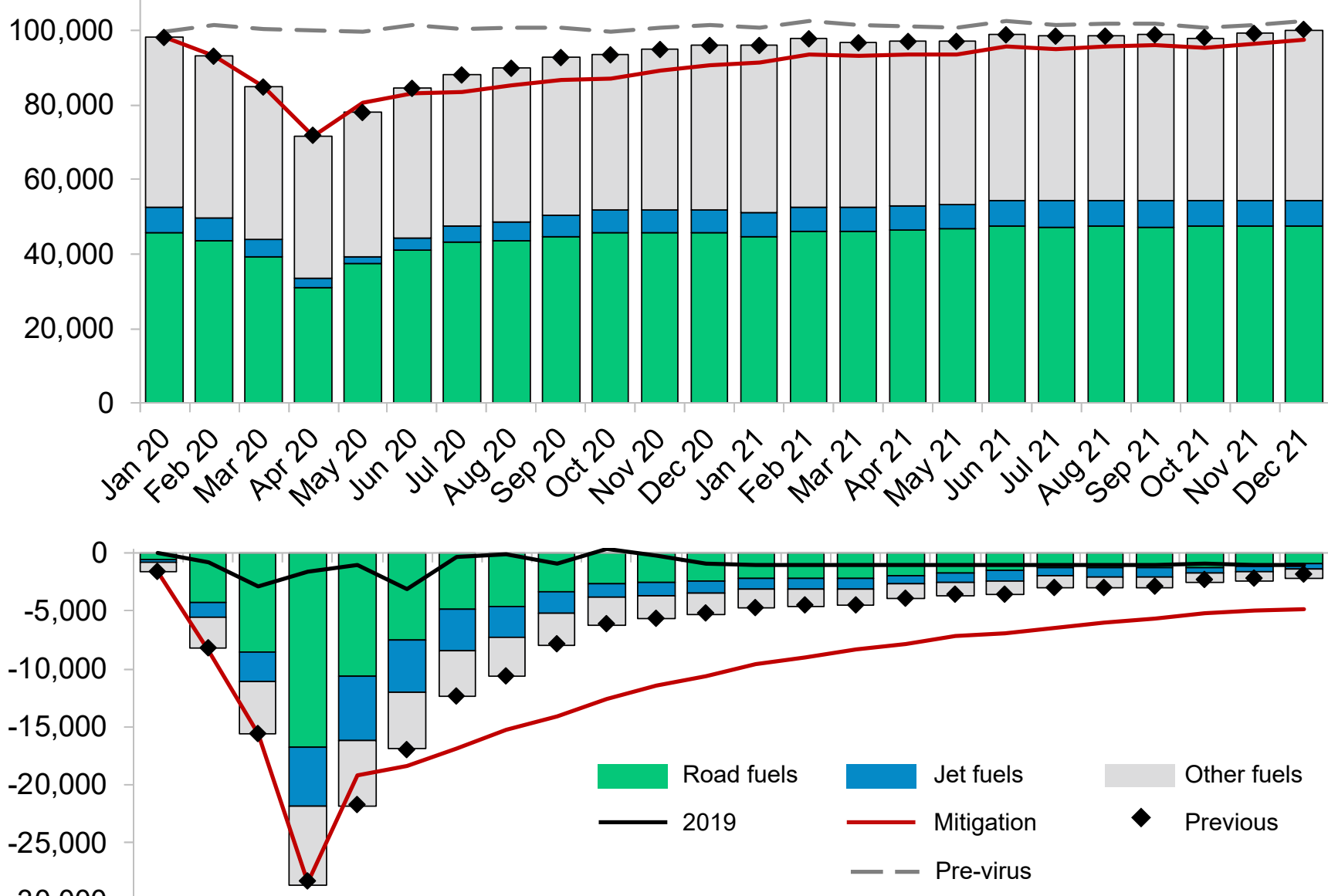

Global demand for road fuel was 31.2 million bpd in April, jet fuel demand was 2.2 million bpd, and demand for all other fuels stood at 38 million bpd.

About 16.7 million bpd was removed from road fuel demand in April, while the decline was 5.2 million bpd for jet fuel and 7 million bpd for all other fuels.

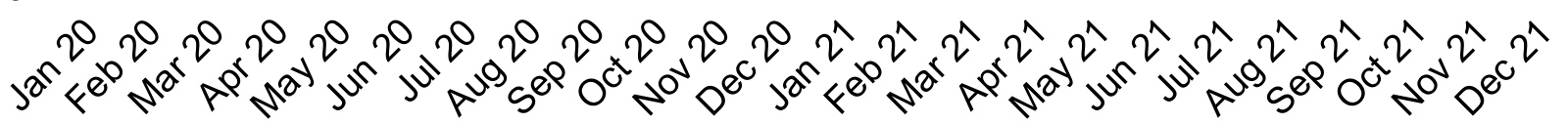




\section{US oil demand recovers in May by 1.7 million bpd vs April}

US oil demand impact analysis of Covid-19 by fuel, levels and changes vs pre-virus estimates Thousand barrels per day

25,000

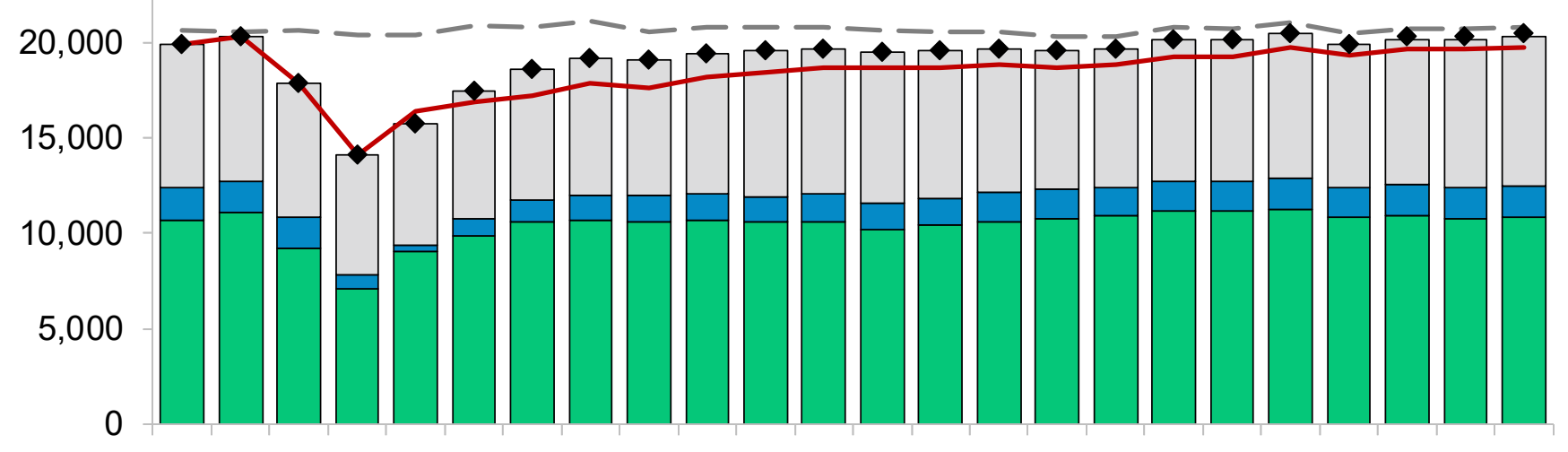

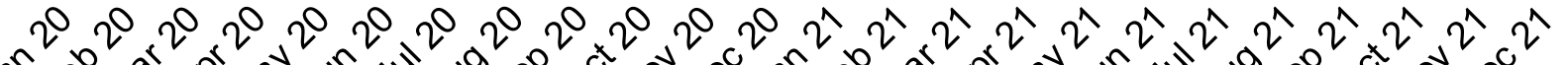

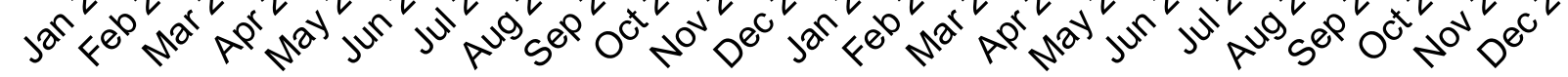
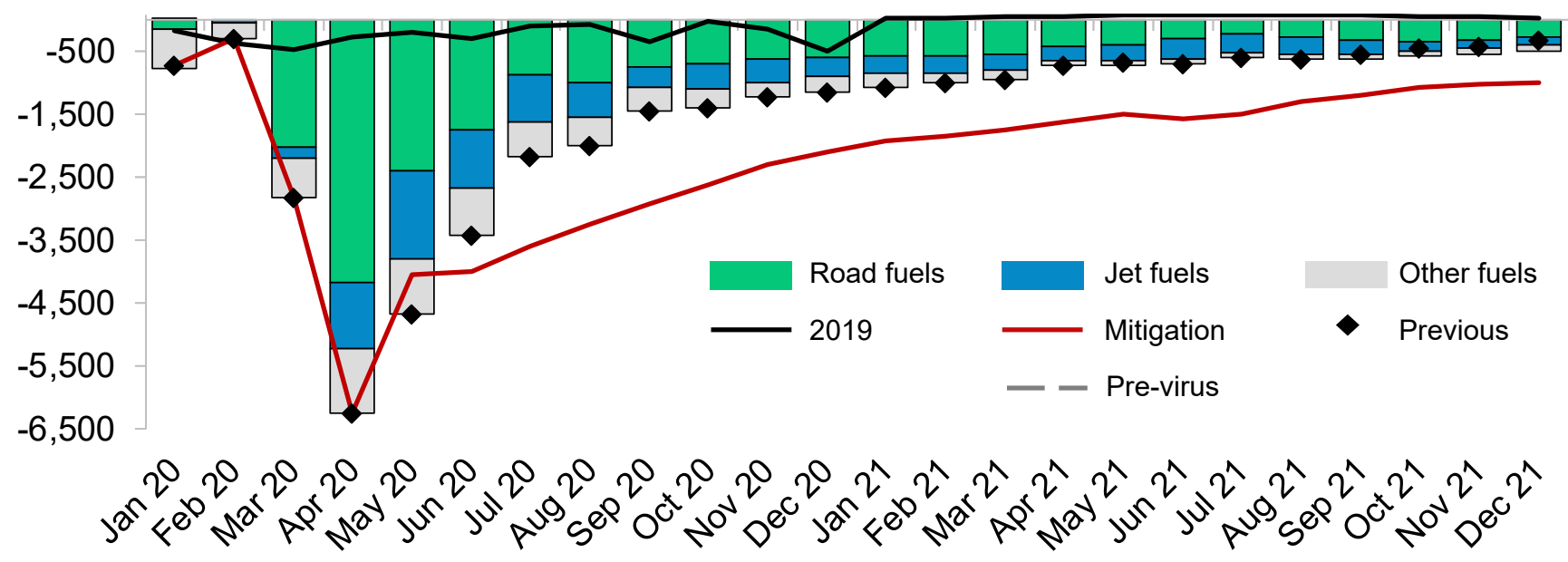

US road fuel demand was 7.1 million bpd in April, jet fuel demand was $700,000 \mathrm{bpd}$ and demand for all other fuels totaled 6.3 million bpd.

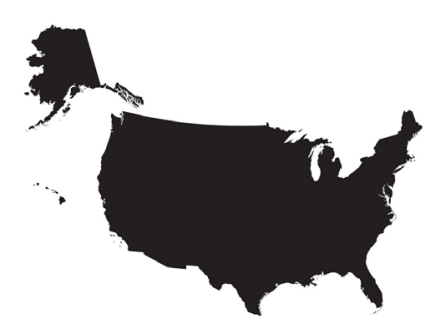

About 4.2 million bpd was removed from US road fuel demand in April, while the decline was 1.3 million bpd for jet fuel and 1 million bpd for all other fuels.

All in all, 880 million barrels will be removed from total demand in the US during the course of 2020. 
Summary data table for total liquids demand after Covid-19 "Effective Containment" case

\begin{tabular}{|c|c|c|c|c|c|c|c|c|c|c|c|c|c|c|c|c|c|c|c|}
\hline & \multicolumn{10}{|c|}{ Million barrels per day } & \multicolumn{9}{|c|}{ Change year-on-year } \\
\hline & \multirow[b]{2}{*}{2019} & \multirow[b]{2}{*}{2020} & \multirow[b]{2}{*}{2021} & \multicolumn{4}{|c|}{2020} & \multicolumn{3}{|c|}{$20201 Q$} & \multirow[b]{2}{*}{2020} & \multirow[b]{2}{*}{2021} & \multicolumn{4}{|c|}{2020} & \multicolumn{3}{|c|}{$20201 Q$} \\
\hline & & & & 1Q & $2 Q$ & $3 Q$ & $4 Q$ & April & May & June & & & 1Q & $2 Q$ & $3 Q$ & $4 Q$ & April & May & June \\
\hline Global & 99.5 & 88.8 & 98.1 & 92.0 & 78.0 & 90.3 & 94.7 & 71.4 & 77.9 & 84.5 & $-10.8 \%$ & $10.5 \%$ & $-7.3 \%$ & $-20.9 \%$ & $-9.8 \%$ & $-5.4 \%$ & $-27.5 \%$ & $-21.1 \%$ & $-14.0 \%$ \\
\hline Road & 47.4 & 42.3 & 46.8 & 42.9 & 36.6 & 43.9 & 45.7 & 31.2 & 37.3 & 41.2 & $-10.8 \%$ & $10.7 \%$ & $-8.0 \%$ & $-22.8 \%$ & $-8.3 \%$ & $-3.8 \%$ & $-34.2 \%$ & $-21.3 \%$ & $-13.0 \%$ \\
\hline Aviation & 7.2 & 4.8 & 6.8 & 5.9 & 2.4 & 4.9 & 6.1 & 2.2 & 1.8 & 3.0 & $-33.5 \%$ & $41.5 \%$ & $-15.9 \%$ & $-67.5 \%$ & $-34.8 \%$ & $-14.7 \%$ & $-68.7 \%$ & $-74.9 \%$ & $-59.2 \%$ \\
\hline Other & 44.9 & 41.7 & 44.4 & 43.2 & 39.0 & 41.5 & 42.9 & 38.0 & 38.8 & 40.3 & $-7.3 \%$ & $6.7 \%$ & $-5.3 \%$ & $-11.0 \%$ & $-7.2 \%$ & $-5.7 \%$ & $-13.5 \%$ & $-12.2 \%$ & $-7.3 \%$ \\
\hline United States & 20.5 & 18.4 & 19.9 & 19.3 & 15.8 & 19.0 & 19.5 & 14.1 & 15.8 & 17.5 & $-10.0 \%$ & $8.2 \%$ & $-4.7 \%$ & $-22.2 \%$ & $-8.3 \%$ & $-5.0 \%$ & $-29.6 \%$ & $-22.1 \%$ & $-15.1 \%$ \\
\hline Road & 11.2 & 10.1 & 10.8 & 10.3 & 8.7 & 10.6 & 10.6 & 7.1 & 9.0 & 9.9 & $-10.5 \%$ & $7.6 \%$ & $-6.2 \%$ & $-24.1 \%$ & $-6.8 \%$ & $-4.6 \%$ & $-36.9 \%$ & $-20.5 \%$ & $-15.1 \%$ \\
\hline Aviation & 1.7 & 1.2 & 1.5 & 1.6 & 0.7 & 1.3 & 1.4 & 0.7 & 0.4 & 1.0 & $-29.0 \%$ & $24.1 \%$ & $-1.7 \%$ & $-62.1 \%$ & $-29.7 \%$ & $-20.4 \%$ & $-59.4 \%$ & $-79.8 \%$ & $-47.2 \%$ \\
\hline Other & 7.5 & 7.1 & 7.6 & 7.4 & 6.5 & 7.1 & 7.5 & 6.3 & 6.4 & 6.7 & $-4.9 \%$ & $6.4 \%$ & $-3.1 \%$ & $-9.4 \%$ & $-5.3 \%$ & $-2.0 \%$ & $-10.7 \%$ & $-10.2 \%$ & $-7.2 \%$ \\
\hline China* & 15.1 & 13.8 & 15.6 & 12.7 & 14.0 & 14.3 & 14.4 & 13.6 & 13.8 & 14.5 & $-8.2 \%$ & $12.6 \%$ & $-15.8 \%$ & $-5.9 \%$ & $-5.3 \%$ & $-5.9 \%$ & $-6.3 \%$ & $-11.3 \%$ & $0.2 \%$ \\
\hline Road & 6.1 & 5.7 & 6.5 & 4.8 & 5.7 & 6.0 & 6.2 & 5.3 & 5.7 & 6.1 & $-7.0 \%$ & $14.9 \%$ & $-22.4 \%$ & $-4.4 \%$ & $-2.6 \%$ & $1.6 \%$ & $-8.7 \%$ & $-9.6 \%$ & $5.7 \%$ \\
\hline Aviation & 0.9 & 0.6 & 1.0 & 0.5 & 0.5 & 0.7 & 0.8 & 0.5 & 0.4 & 0.5 & $-29.4 \%$ & $51.1 \%$ & $-36.7 \%$ & $-46.2 \%$ & $-25.4 \%$ & $-10.2 \%$ & $-42.6 \%$ & $-51.5 \%$ & $-44.5 \%$ \\
\hline Other & 8.1 & 7.5 & 8.1 & 7.4 & 7.8 & 7.5 & 7.4 & 7.8 & 7.7 & 7.9 & $-6.7 \%$ & $7.6 \%$ & $-8.4 \%$ & $-2.5 \%$ & $-4.8 \%$ & $-10.9 \%$ & $-0.7 \%$ & $-8.2 \%$ & $1.8 \%$ \\
\hline Europe & 14.2 & 12.4 & 13.6 & 13.1 & 10.2 & 12.8 & 13.5 & 9.0 & 10.0 & 11.4 & $-13.2 \%$ & $10.3 \%$ & $-7.3 \%$ & $-28.5 \%$ & $-12.4 \%$ & $-4.6 \%$ & $-37.5 \%$ & $-28.4 \%$ & $-19.3 \%$ \\
\hline Road & 7.0 & 6.2 & 6.7 & 6.4 & 5.0 & 6.5 & 6.8 & 4.1 & 5.0 & 6.0 & $-12.0 \%$ & $8.8 \%$ & $-5.7 \%$ & $-28.3 \%$ & $-9.6 \%$ & $-4.4 \%$ & $-42.7 \%$ & $-27.2 \%$ & $-14.8 \%$ \\
\hline Aviation & 1.5 & 0.9 & 1.4 & 1.1 & 0.2 & 0.9 & 1.2 & 0.2 & 0.2 & 0.3 & $-39.3 \%$ & $54.9 \%$ & $-14.0 \%$ & $-84.8 \%$ & $-42.3 \%$ & $-10.8 \%$ & $-88.3 \%$ & $-88.1 \%$ & $-78.3 \%$ \\
\hline Other & 5.7 & 5.3 & 5.5 & 5.5 & 4.9 & 5.3 & 5.4 & 4.8 & 4.8 & 5.1 & $-8.0 \%$ & $4.4 \%$ & $-7.6 \%$ & $-13.6 \%$ & $-7.4 \%$ & $-3.3 \%$ & $-18.1 \%$ & $-14.1 \%$ & $-8.2 \%$ \\
\hline
\end{tabular}


Table of Contents

\section{Executive summary}

\section{Outbreak status and outlook}

Impact on oil demand

Impact on the oil and gas industry

- Global market outlook

- Market segment focus

\section{Methodology}


Global E\&P investments expected to fall more than $25 \%$ this year

Global Investments*

Billion USD

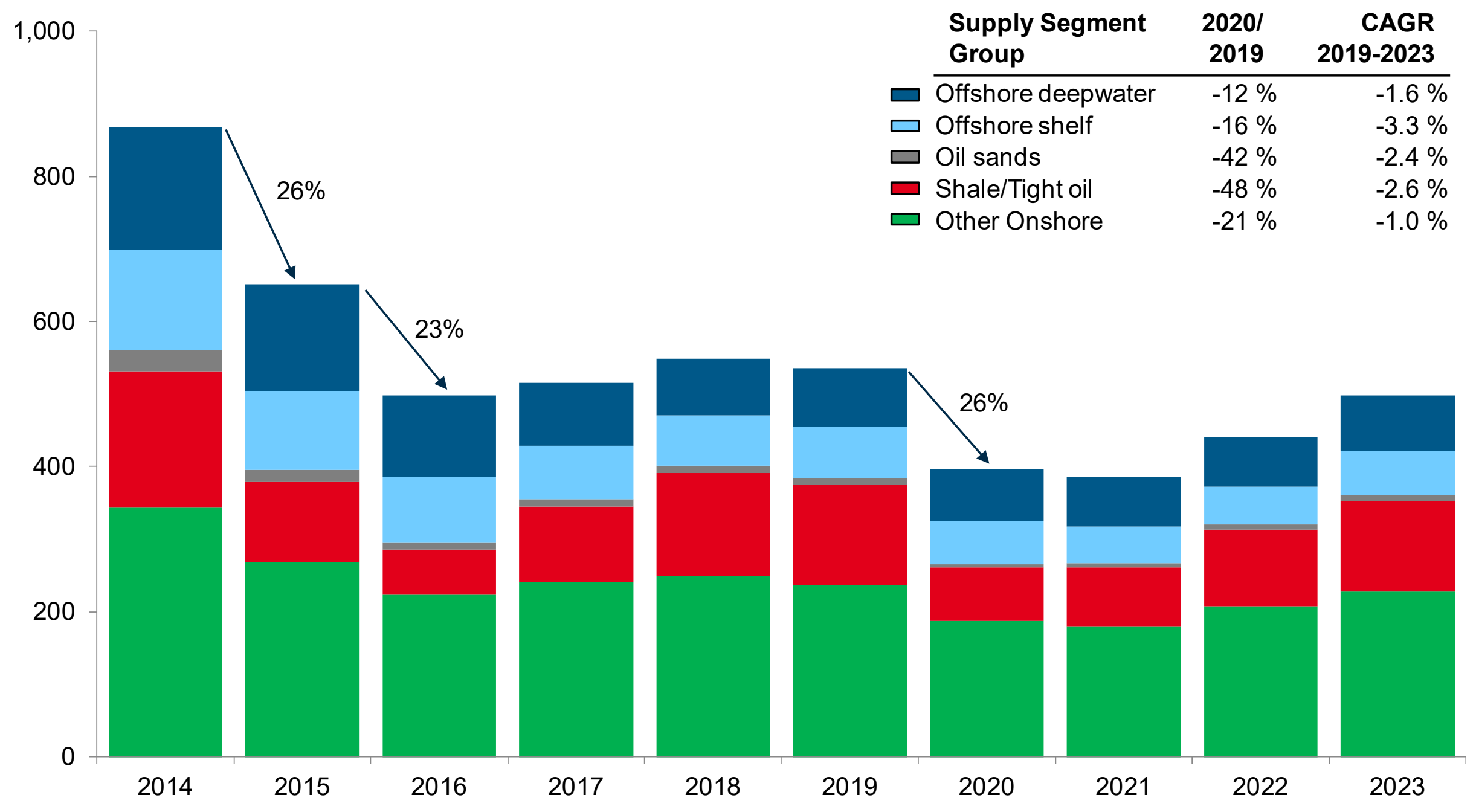

*Investments include greenfield, brownfield and exploration capex Source: Rystad Energy UCube 
Global market outlook

Global FID activity to slip significantly

Total conventional sanctioning of greenfield investments (capex committed each year) Billion USD

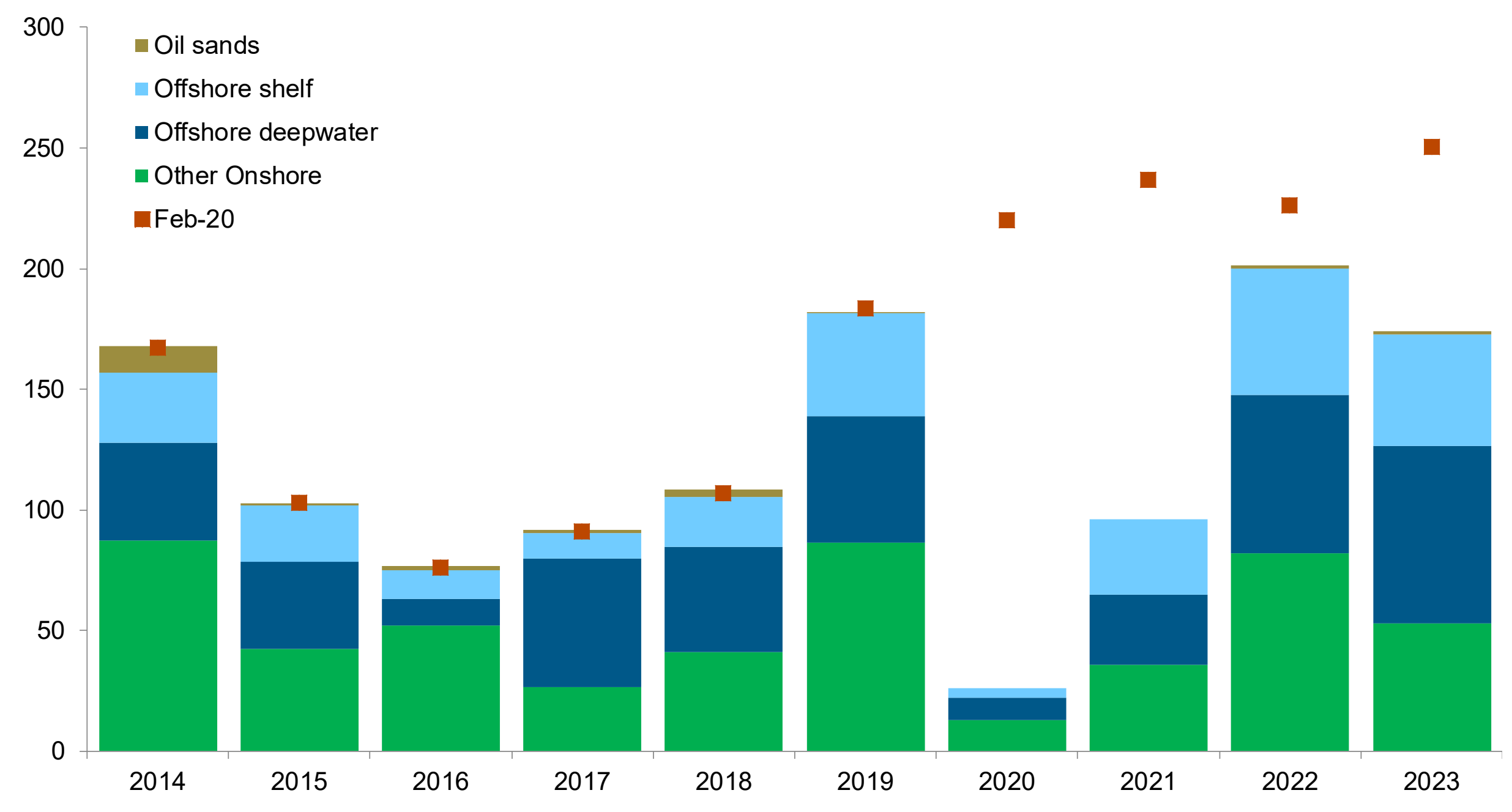


OPEC+ helped by core OPEC ME extra cuts surprise with high compliance (latest)

\section{OPEC+ oil* production, monthly}

Million barrels per day

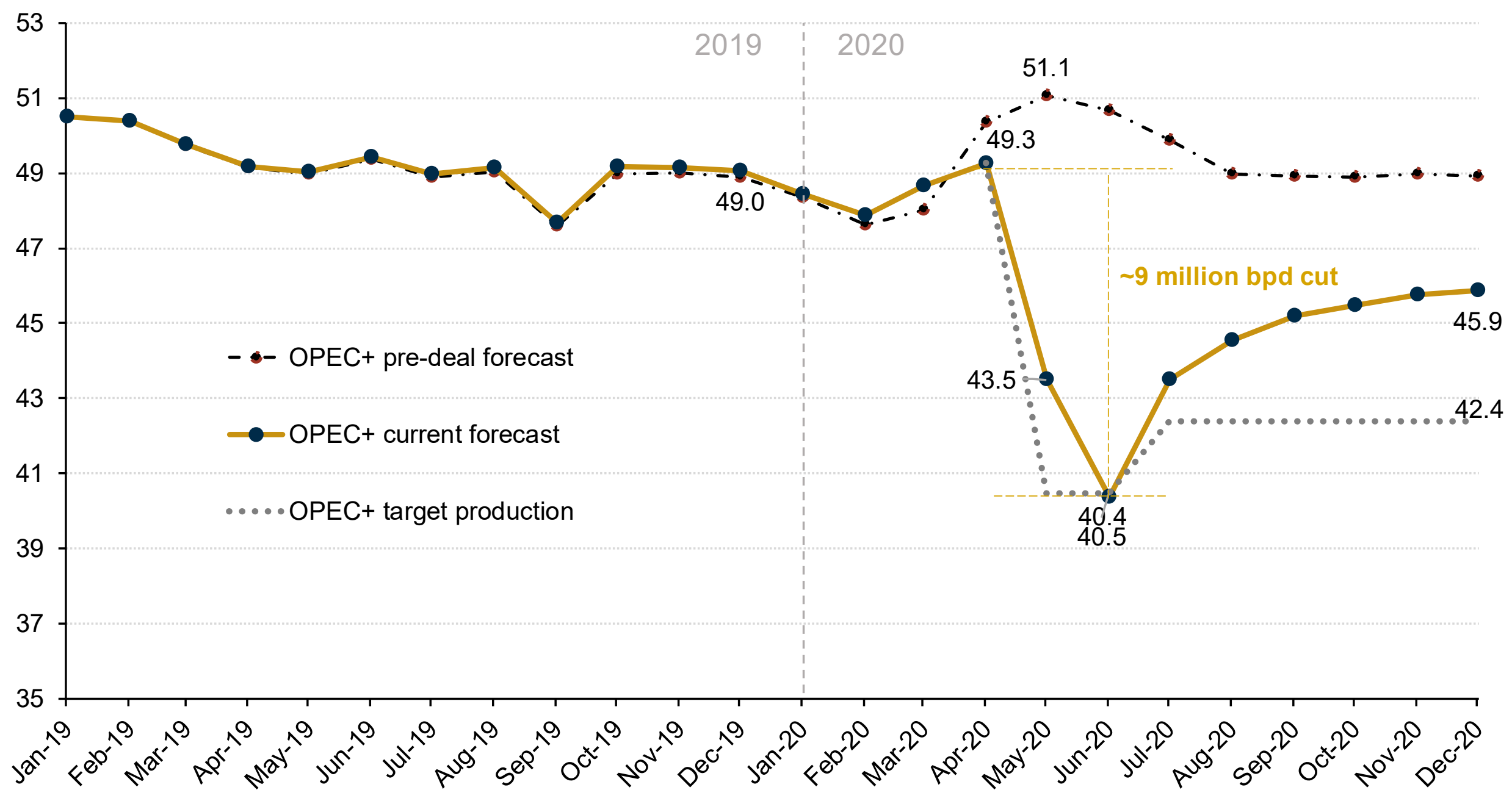

${ }^{*}$ OPEC + oil here includes OPEC-13 and non-OPEC-10 crude and lease condensate Source: Rystad Energy research and analysis, OilMarketCube 
Fracking operations have tumbled even more than drilling

Number of wells

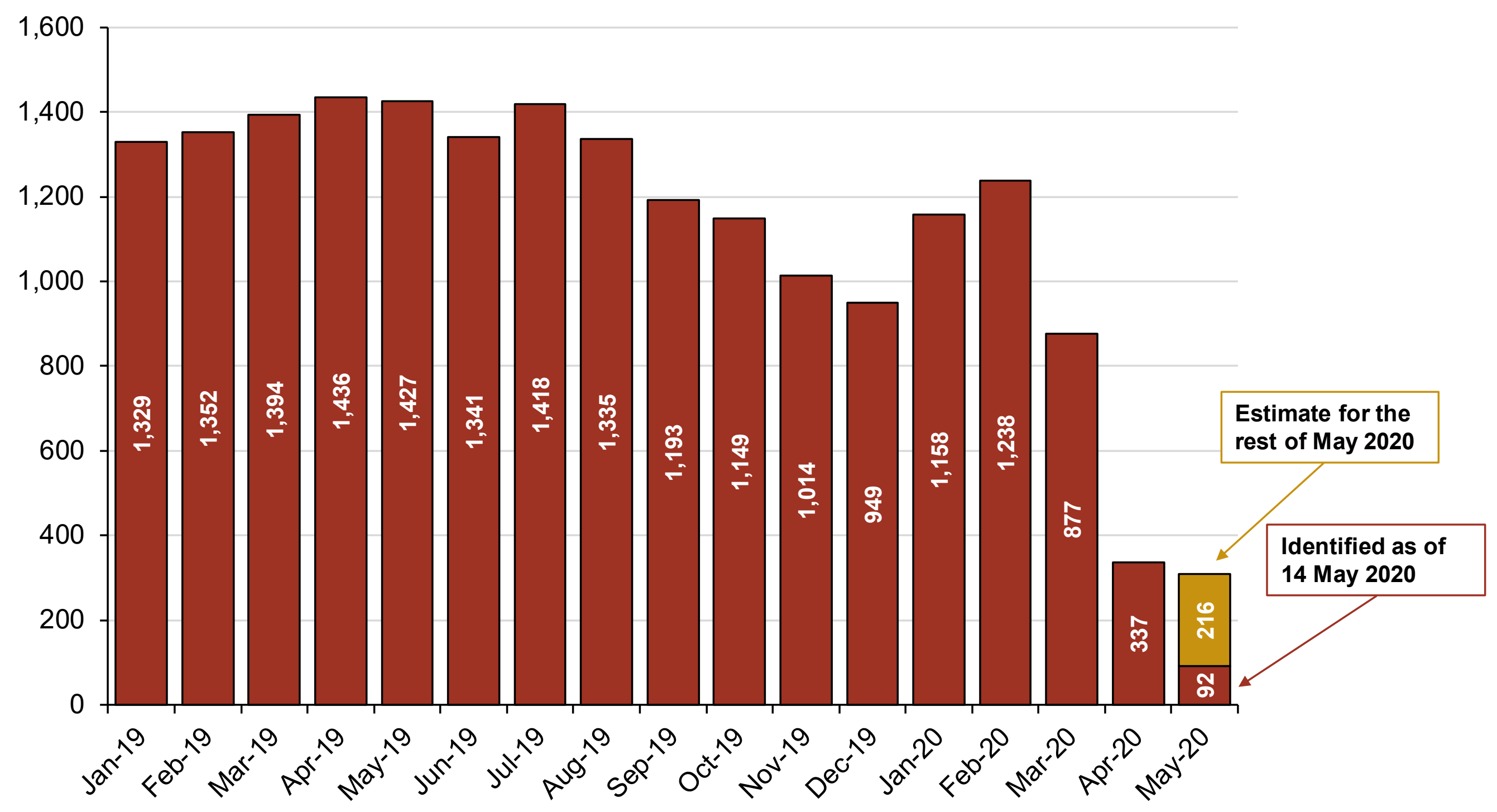


Market segment focus

US oil* production outlook by forecast time stamp and scenario Thousand barrels per day

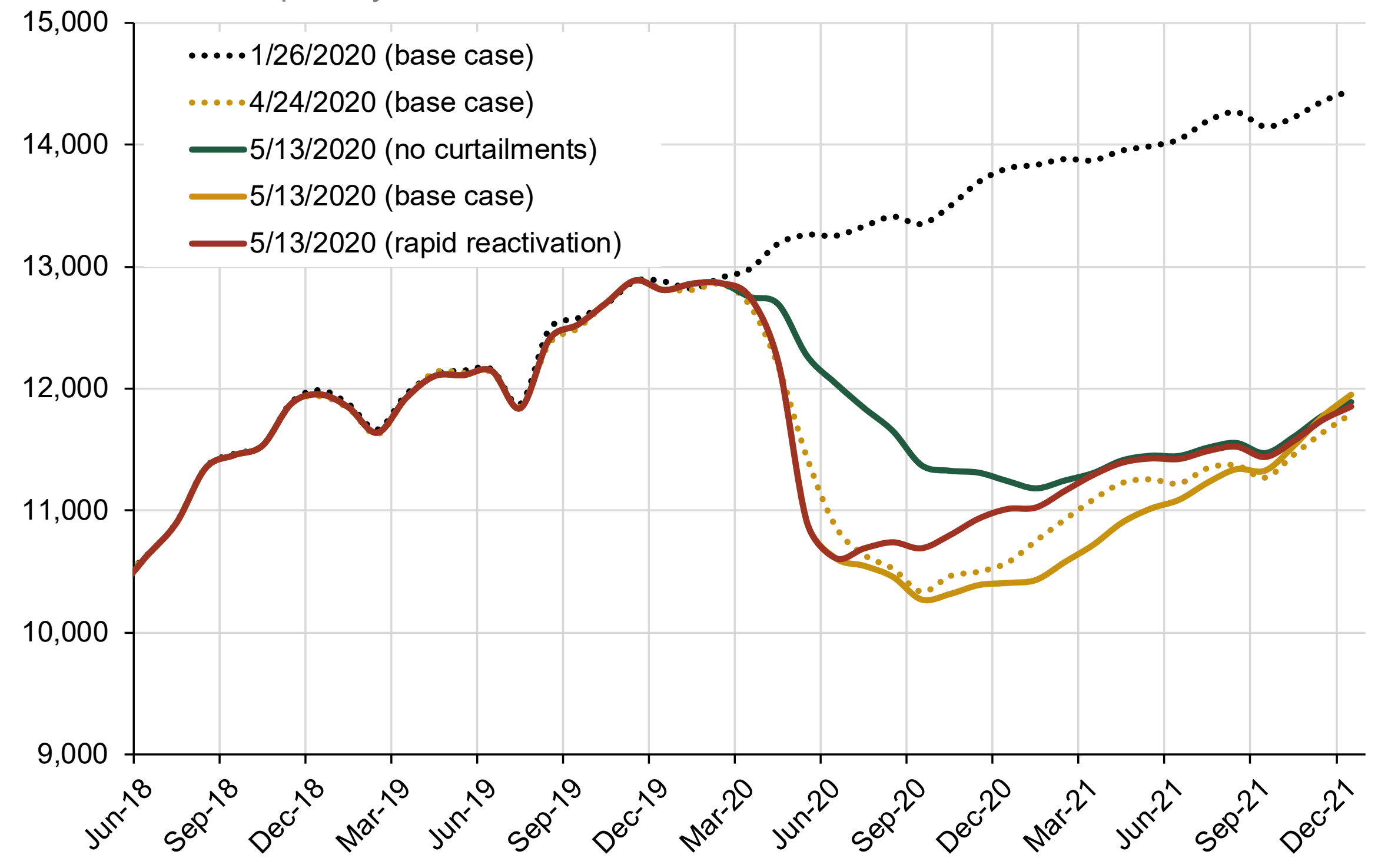

${ }^{*}$ Crude oil and lease condensate production

Source: Rystad Energy ShaleWellCube, Rystad Energy OilMarketCube, Rystad Energy research and analysis 


\section{Year-on-year change, index normalized to $2014=100$ for each segment}

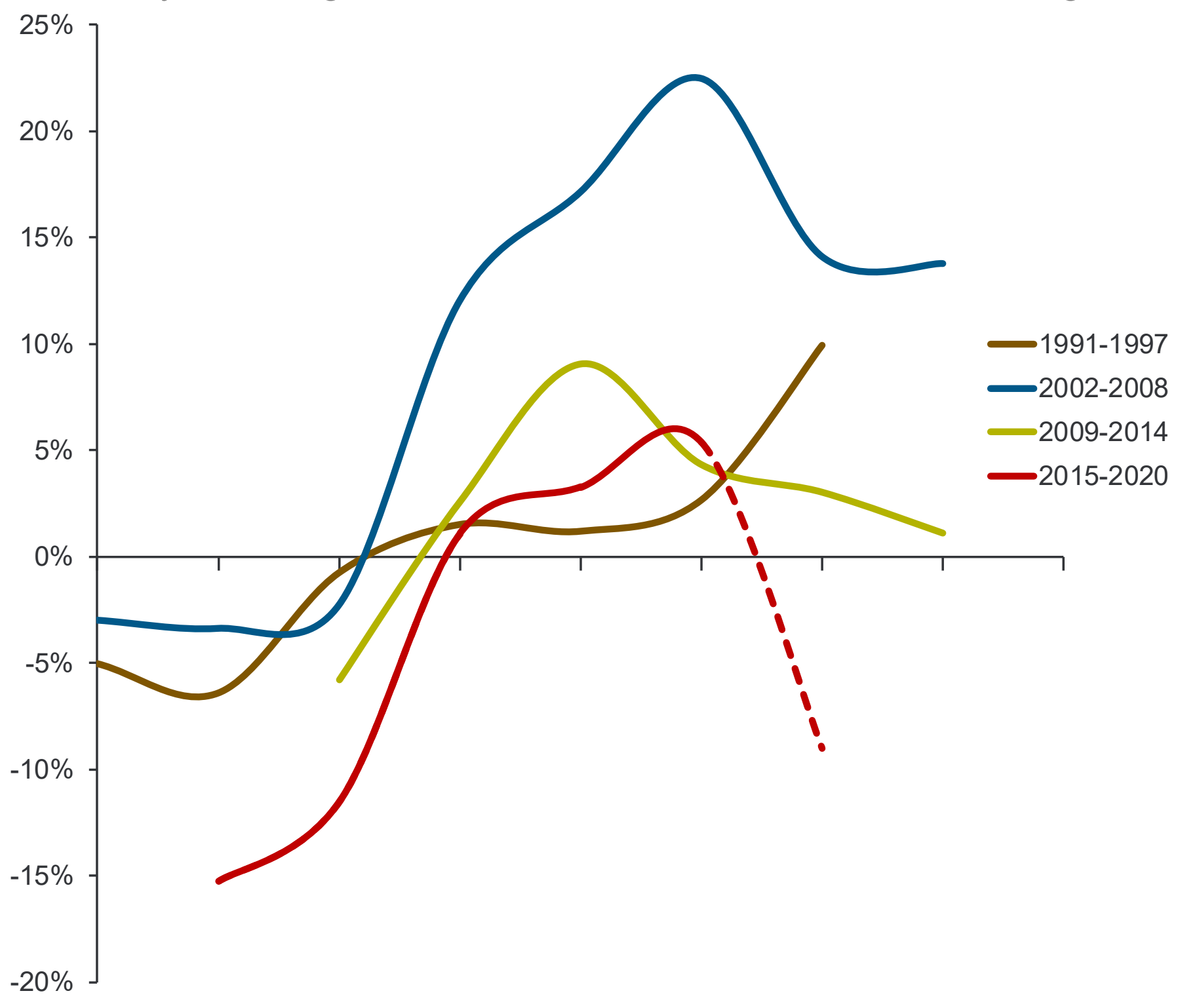

Comparing the current cycle that we're in against previous cycles over the past three decades, two key takeaways can be identified:

- The cost deflation seen from 2015 through 2018 was the most dramatic when compared against the previous three major cycles

- The duration of cost inflation in the upturn of the cycle also was the shortest duration when compared against the previous cycles dating back to 1990

These two factors combined mean the service industry not only saw prices decrease dramatically, but also was denied the expected cost relief that had applied in previous cycles.

Current service pricing is squeezed and has not managed to grow in the same manner as was seen throughout other cycles over the past 30 years. The good news with this downturn, however, is that service price reduction will happen organically.

Source: Rystad Energy Cost Solutions, May 2020 


\section{Stay updated on our COVID-19 content}

In order for you to stay up to date on our releases regarding COVID-19 and the impact on the energy sector, we have two options for you:

\section{Sign up for Rystad Energy's Free Solutions:}

As an industry professional you can sign up to Rystad Energy's Free Solutions here. You will get full access to the library of free COVID-19 related releases and other energy related analytics and dashboards.

\section{Sign up for e-mail notifications:}

Sign up here to get immediate email notification when Rystad Energy publishes a new report / new press release associated to COVID-19. 


\section{OIL MARKET WEEKLY}

RYSTAD ENERGY PRODUCT RELEASE

OIL MARKET WEEKLY - Demand report, a weekly report with:

- An overview of global oil demand

- Oil demand impact in two COVID-19 mitigation scenarios

- Impact of oil demand in aviation, ground transportation and road fuels

OIL MARKET WEEKLY - Balances report:

- A weekly Commentary with the latest oil market observations

- A weekly Executive Summary on the oil market balances, oil supply and demand, and the overall oil market view

OIL MARKET DASHBOARDS and Excel data on:

- Oil demand analysis dashboard: split by country, transport type, aviation

- COVID-19 dashboard: oil demand impacting two COVIDI 9 mitigation scenarios 


\section{(5)}

\section{RYSTAD ENERGY}

Rystad Energy is an independent energy consulting services and business intelligence data firm offering global

databases, strategy advisory and research products for

energy companies and suppliers, investors, investment banks, organizations, and governments. Rystad Energy's headquarters are located in Oslo, Norway.

\section{Headquarters}

Rystad Energy

Fjordalléen 16, 0250 Oslo, Norway

Americas +1 (281)-231-2600

EMEA +47908 87700

Asia Pacific +6569093715

Email: support@rystadenergy.com

(c) Copyright. All rights reserved.

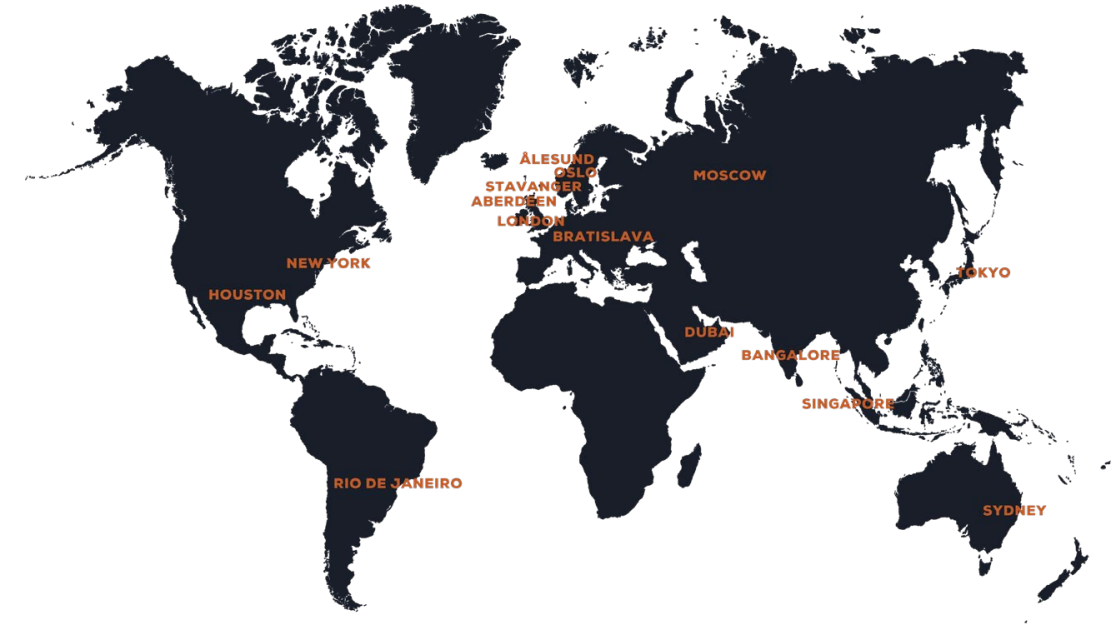

